Original article

Section: Food Chemistry

\title{
Variation in the Phenolic Compounds Profile and Antioxidant Activity in Different Parts of Hawthorn (Crataegus pentagyna Willd.) During Harvest Periods
}

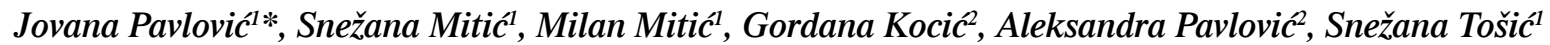 \\ ${ }^{1}$ Department of Chemistry, Faculty of Science and Mathematics, University of Niš, Višegradska 33, 18000 Niš, Serbia \\ ${ }^{2}$ Department of Biochemistry, Faculty of Medicine, University of Niš, Bulevar dr Zorana Đinđića 81, 18000 Niš, Serbia
}

Key words: phenolic compounds, Crataegus pentagyna Willd., RP-HPLC, principal component analysis, leaves, flowers, fruits

Plants of the genus Crataegus, Rosaceae, are widely distributed and have long been used for food and in folk medicine for the treatment of various ailments. This study focused on HPLC-DAD-FLD identification of phenolic compounds of flowers, fruits, and leaves of hawthorn (Crataegus pentagy$n a$ Willd.), on monitoring changes in the content of phenolic compounds during different harvesting periods, as well as on the in vitro testing of the antioxidant activity. Study results showed that neochlorogenic and chlorogenic acids ( 5.2 and $4.85 \mathrm{mg} / \mathrm{g}$ dry weight, respectively) were the most abundant phenolic compounds in the flowers. (-)-Epicatechin and procyanidin B2 were the most abundant phenolic compounds in leaves and fruits. The highest content of phenolic compounds was found in leaves harvested in the early maturity stages, with a tendency of declining in the later stages of maturity. On the other hand, in the case of fruits, the most noticeable changes were found in the content of flavan-3-ols. The highest content of (-)-epicatechin $(21.1 \mathrm{mg} / \mathrm{g}$ fresh weight) in fruit was in August, and those of procyanidins B2 and B5 in September (10.6 and $3.74 \mathrm{mg} / \mathrm{g}$ fresh weight, respectively). Statistical analysis showed a strong correlation between the total phenolics content and the antioxidant activity. This study has demonstrated that there is seasonal variation in both the quantity and the type of phenolic compound as well as the antioxidant activity of different parts of hawthorn.

\section{INTRODUCTION}

Knowledge and experience of herbal treatment acquired for centuries have been held up to this day as traditional medicine. In addition to the application in health care, medicinal and aromatic plants are increasingly used in various industries: pharmaceutical, food, cosmetic, chemical, and others. Such extensive application has contributed to the increase in economic significance of medicinal and aromatic plants and provided the possibility of revenue on different levels of production, processing, and distribution. Frequent and widespread use of herbs throughout the world has increased significant concerns over their quality, safety, and efficacy. Thus, sound scientific evidence or assessment have become the criteria for acceptance of traditional health claims. The genus Crataegus comprises of a complex group of trees and shrubs native to Northern temperate zones, mostly between latitudes $30^{\circ}$ and $50^{\circ} \mathrm{N}$. Crataegus belongs to the subfamily Maloideae in the Rosaceae, a natural group of complex genera with the ability to interbreed freely [Albarouki \& Peterson, 2007; Kumar et al., 2012]. There are over 1000 species of Crataegus distributed primarily in Asia, Europe, and North America [Zhao \& Tian, 1996]. Different species dominate and different parts of the plant are used in these regions. For example, Crataegus pinnatifida Bge. and Crataegus scabrifolia

\footnotetext{
* Corresponding Author: E-mail: jovanapavlovic@ymail.com (J. Pavlović)

are the most important species in China, whereas Crataegus laevigata Poir. (syn: Crataegus oxyacantha L.), Crataegus monogyna Jacq., Crataegus pentagyna Waldst., Crataegus nigra Waldst., and Crataegus azarolus L. are the major species in Europe [Rayyan et al., 2005; Liu et al., 2011].

Crataegus species have long been used in traditional Chinese and European herbal medicine. In addition to being highly recommended in folk medicine, hawthorn berries are valuable food ingredient due to the content of nutrients and compounds with health benefits [Bernatoniene et al., 2008; Tadić et al., 2008]. Hawthorn berries are used to prepare jams, jelly, drinks, wine, and canned fruit.

Fruits and leaves of hawthorn are rich in phenolic compounds, which are considered to be the key bioactive compounds in this plant, accounting for its antioxidant activity and other beneficial biological effects [Bleske et al., 2008]. The main components of hawthorn are thought to be flavones, flavonols, flavan-3-ols (especially (-)-epicatechin), and flavan-3-ol oligomers (procyanidins) [Liu et al., 2011; Svedström et al., 2006; Yang \& Liu, 2012]. Oligomeric procyanidins and their glycosides are the major phenolic compounds in fruits, whereas flavonols, flavonol glycosides, and $C$-glycosyl flavones dominate in leaves [Liu et al., 2011]. On the basis of literature data, quercetin, kaempferol, and sexangularetin are the major flavonols in hawthorn [Yang \& Liu, 2012]. Rutin and hyperoside are the predominant flavonol glycosides, while vitexin, vitexin-2"-O-rhamnoside, 
and acetylvitexin-2"-O-rhamnoside are the most prevalent flavone glycosides [Liu et al., 2011].

Various factors (climatic, agronomic, genomic, preand post-harvest conditions, and processing) may affect the chemical composition of plant foods and may have a significant role in determining the phenolic composition and the bioactivity of these compounds [el Amira et al., 2012; Imeh \& Khokhar, 2002]. Contents of phenolics are often dependent on pre- and post-harvest factors such as species, environmental characteristics, agronomic features, ripeness, harvesting, storage, etc. [Routray \& Orsat, 2014; Tiwari \& Cummins, 2013]. Owing to all the above mentioned, many types of researches have addressed changes in the content of bioactive components of plants [Ben Ahmed et al., 2017; Cezarotto et al., 2017; Hlel et al., 2017; Rimkiene et al., 2017].

As mentioned above, the composition and the content of phenolic compounds in hawthorn vary between different parts of the same plant and differ significantly depending on the origin and species of hawthorn. The maturity stage is also an important factor that may influence the compositional quality of hawthorn. Bearing in mind that the plant chemical composition is conditioned by all of the above, it is essential to evaluate the optimal cultivation time in order to obtain the highest amount of bioactive compounds. The aim of our research was to investigate the qualitative and quantitative composition and the antioxidant activity of phenolic compounds in different parts of hawthorn plant (C. pentagyna Willd.) and also to provide information about composition changes within different harvest periods.

\section{MATERIAL AND METHODS}

\section{Chemical and reagents}

The following reagents were used: 2,2'-azino-bis(3-ethylbenzothiazoline-6-sulfonic acid) (ABTS), 2,2'-diphenyl-1-picrylhydrazyl (DPPH), Folin Ciocalteu's phenol reagent, neocuproine, potassium peroxodisulfate, ammonium iron(II) sulfate hexahydrate, iron(III) chloride, potassium hexacyanoferrate(III), sodium hydroxide, sodium carbonate, sodium dihydrogen phosphate, sodium hydrogen phosphate, trichloroacetic acid, hydrochloric acid, acetic acid, formic acid, and acetonitrile (Merck, Darmstadt, Germany). The following certification standards were also used: $p$-coumaric acid, caffeic acid, chlorogenic acid, ferulic acid, quercetin, quercetin 3-O-glucoside (isoquercetin), quercetin 3-O-rutinoside (rutin), kaempferol 3-O-glucoside, (-)-epicatechin, hyperoside, luteolin, apigenin, cyanidin 3-O-glucoside, procyanidins B1 and B2 (Sigma Aldrich, Steinheim, Germany). 6-Hydroxy-2,5,7,8-tetramethylchroman-2-carboxylic acid (Trolox) was purchased from Acros Organics (Morris Plains, New Jersey, USA). Solutions were prepared using deionized water (specific conductivity $0.05 \mu \mathrm{S} / \mathrm{cm}$ ) which was produced using MicroMed high purity water systems (TKA Wasseraufbereitungssysteme GmbH, Niederelbert, Germany).

\section{Plant material}

Hawthorn (C. pentagyna Willd.) flowers, fruits, and leaves were picked from the field in Bela Palanka, Serbia, from May 19 to October 6, 2015, at roughly one-month intervals. One flower sample, four fruit samples, and five leaf samples were collected at each harvest date. Three shrubs were randomly chosen in the field for the uniformity of tree development, light exposure, and health. Leaves were collected in May and June, from the apical position of ten young growing shoots of comparable length and position near the base of each shrub. The leaves from each shoot were pooled together. Leaves from July to September were collected from three different positions on three different shrubs: basal, middle, and terminal. Leaves from each shrub were pooled together. Immediately after the harvest, the fruits were frozen and stored at $-18^{\circ} \mathrm{C}$ until analysis, while flowers and leaves were air dried in shade and ground.

\section{Extraction}

Plant material was extracted by maceration, combined with ultrasound-assisted solvent extraction. Hawthorn fruit was defrosted and blended. Defrosted tissue, dried flower, and leaves $(0.2 \mathrm{~g}$ of each) were mixed with $15 \mathrm{~mL}$ of $80 \%$ acetone and kept at room temperature for $48 \mathrm{~h}$. Afterwards, liquid was decanted, while the residual plant material (marc) and the rest of the liquid were transferred to a Büchner funnel (diameter $55 \mathrm{~mm}$ ) for pressure-assisted filtration and pressed with porcelain discs $(500 \mathrm{~g})$ of the same diameter as the Büchner funnel for $30 \mathrm{~min}$. The obtained decanted, filtrated, and pressed out liquids were mixed together. Subsequently, the marc was subjected to ultrasound-assisted extraction for 15 min with $10 \mathrm{~mL}$ of $80 \%$ acetone, five successive times. The liquid after each ultrasound-assisted extraction step was collected and pooled together with the liquid obtained previously from maceration. The pooled extraction liquid was filtrated through Whatman filter paper (black ribbon) and supplemented with $80 \%$ acetone to the final volume of $50 \mathrm{~mL}$ [Bravo \& Mateos, 2008; Katalinic et al., 2010; Munhoz et al., 2014].

\section{Determination of total phenolics content}

Total phenolics (TP) content was determined with the spectrophotometric method using the Folin-Ciocalteu's phenol reagent [Singleton et al., 1999]. Briefly, $50 \mu \mathrm{L}$ of each acetone extract was mixed with $0.25 \mathrm{~mL}$ of the Folin-Ciocalteu reagent and $1 \mathrm{~mL}$ of $20 \%(\mathrm{w} / \mathrm{v})$ sodium carbonate solution, and made up to $10 \mathrm{~mL}$ with deionized water. After standing for $2 \mathrm{~h}$ at room temperature, absorbance was measured at $760 \mathrm{~nm}$ using an Agilent UV/VIS spectrophotometer (Agilent Technologies, Santa Clara, CA, USA). Results were expressed as $\mathrm{mg}$ of gallic acid equivalents per $\mathrm{g}$ of dry weight (mg GAE/g dry weight) for leaves and flowers and as $\mathrm{mg}$ of gallic acid equivalents per $\mathrm{g}$ of fresh weight (mg GAE/g fresh weight) for fruits. All measurements were performed in triplicate.

\section{High-performance liquid chromatography (HPLC)}

Qualitative analysis of phenolic acids, flavonols, flavan-3-ols, flavones, and anthocyanins was performed with the HPLC, employing a direct injection method [Mitic et al., 2012]. The analysis was performed using the HPLC system (Agilent 1200 series, Agilent Technology, Santa Clara, CA, USA), equipped with four solvent delivery units G1354A, diode array detector (DAD) G1315D, fluorescence detec- 
tor (FAD) G1321A, and HP Chemstation chromatography workstation. Chromatographic analyses were performed on $150 \mathrm{~mm}$ x $4.6 \mathrm{~mm}$ i.d., Zorbax Eclipse XDB $\mathrm{C}_{18}$ column (Agilent Technologies, Santa Clara, CA, USA). The column was thermostated at $30^{\circ} \mathrm{C}$. The flow rate was $0.8 \mathrm{~mL} / \mathrm{min}$ and the injection volume was $5 \mu \mathrm{L}$. The mobile phase were: A: $\mathrm{H}_{2} \mathrm{O}-\mathrm{HCOOH}(95: 5, \mathrm{v} / \mathrm{v})$ and $\mathrm{B}: \mathrm{ACN}-\mathrm{HCOOH}-\mathrm{H}_{2} \mathrm{O}$ $(80: 5: 15, \mathrm{v} / \mathrm{v} / \mathrm{v})$. The gradient procedure was: $0-10 \mathrm{~min}$ with $0 \% \mathrm{~B}, 10-28 \mathrm{~min}$ gradually increases $0-25 \% \mathrm{~B}$, from 28 to $30 \mathrm{~min} 25 \% \mathrm{~B}$, from 30 to 35 min gradually increases $25-50 \% \mathrm{~B}$, from 35 to $40 \mathrm{~min}$ gradually increases $50-80 \% \mathrm{~B}$, and finally for the last $5 \mathrm{~min}$ gradually decreases $80-0 \%$ B. Eluate was monitored at $280 \mathrm{~nm}, 320 \mathrm{~nm}, 360 \mathrm{~nm}$, and $520 \mathrm{~nm}$ with $\mathrm{DAD}$, for the identification of flavones, flavonols, hydroxycinnamic acids, and anthocyanins. Four flavan-3-ols including: (-)-epicatechin, procyanidin $\mathrm{B}$, procyanidin $\mathrm{B} 5$, and procyanidin $\mathrm{B} 2$, were monitored at $275 / 322 \mathrm{~nm}\left(\lambda_{\mathrm{Ex}} / \lambda_{\mathrm{Em}}\right)$ with FLD. Phenolics present in the samples were identified by comparing their retention times and spectra with those of pure components. Quantification of components was performed using external standards. For each standard, stock solutions $(1.0 \mathrm{mg} / \mathrm{mL})$ were prepared in $10 \%(\mathrm{v} / \mathrm{v})$ methanol. Concentrations of components in the samples were calculated from the equation obtained from calibration graphs, constructed for each standard, while for components without the appropriate standard, quantification was performed based on a calibration graph plotted for structurally similar standards, i.e: $p$-coumaric acid was used to express content of 4-O-coumaroylquinic acid; chlorogenic acid was used as the standard for 4-O-caffeoylquinic acid (cryptochlorogenic acid) and 5- $O$-caffeoylquinic acid (neochlorogenic acid); kaempferol 3-O-glucoside, quercetin 3-O-rutinoside, luteolin and apigenin were used to express contents of kaempferol rutinoside, quercetin rhamnoside, luteolin and apigenin derivatives, respectively; (-)-epicatechin was the standard for procyanidin B2, B5 and PC derivative; and cyanidin 3-O-glucoside for ideain (cyanidin 3-O-galactoside). All chemicals and solvents were of analytical or HPLC purity. All analyses were performed in triplicate.

\section{Antioxidant activity assays}

The antioxidant capacities of hawthorn parts (flowers, fruits, and leaves) were studied in four antioxidant assays: scavenging DPPH radical [Brand-Williams et al., 1995], scavenging ABTS radical cation [Re et al., 1999], iron (III) to iron(II) reduction power (FRP) assay [Oyaizu, 1986], and cupric ion reducing antioxidant capacity (CUPRAC) assay [Apak et al., 2006]. The antioxidant activities of hawthorn from all the assays were expressed as $\mu$ mol of Trolox equivalent (TE) per $g$ of fresh weight of fruits and dry weight of flowers and leaves.

\section{Statistical analysis}

Correlation statistical analysis was performed using Statistica software (StatSoft 8.0, Tulsa, Oklahoma, USA). Data were expressed as mean values and standard deviations (SD). Correlation analysis between the total phenolics content, the antioxidant activities of four independent assays (DPPH, ABTS, CUPRAC, and FRP) and the sum of contents of com- pounds from different classes of phenolics was performed with the bivariate (Pearson's) correlation test at a significance level of $\mathrm{p}<0.05$.

The analysis of variance (one-way ANOVA) was applied on the following set of variables: quantitative variables (total phenolics content, content of individual phenolics, the sum of the contents of phenolic compounds belonging to different classes, and the antioxidant activity measured by four different assays) and qualitative (explanatory) variable: harvest period (leaves and fruit samples harvested in different periods). Tukey's Honestly Significantly Different (HSD) test was applied to pairwise all differences between means at $\mathrm{p}<0.05$.

The principal component analysis (PCA) was applied on the following set of variables: content of individual phenolic compounds in flower, fruit, and leaves, and the sum of the contents of individual phenolic compounds belonging to different classes (hydroxycinnamic acids, flavonols, flavones, flavan-3-ols, and anthocyanins), as well on the sum of the contents of individual phenolic compounds belonging to different classes in leaves and fruits and the antioxidant activity measured by four different methods. Each principal component was calculated by using linear combination of eigenvectors of the correlation matrix with original values. PCA and ANOVA were performed using Excel plug-in program XLSTAT, version 2014.4 (Addinsoft, New York, NY, USA).

\section{RESULTS AND DISCUSSION}

\section{Total and major classes phenolics content}

Total phenolics content of hawthorn flowers, fruits, and leaves is presented in Table 1. The sum of the contents of phenolic compounds from particular classes is presented in Tables 2 and 3 .

Measured with a colorimetric method, the content of total phenolics varied between 84 and $128 \mathrm{mg} / \mathrm{g}$ dry weight in flowering tops (flowers and leaves) and between 36.7 and $53.8 \mathrm{mg} / \mathrm{g}$ fresh weight in fruits. The sum of the contents of the phenolic compounds measured with the HPLC method was the highest in fruits harvested in August-September (37.8-39 mg/g dry weight) (Table 2) and in leaves harvested in June $(41.6 \mathrm{mg} / \mathrm{g}$ dry weight) (Table 3). The majority of phenolic compounds in leaves reached the maximum in mid-June, with a clear declining pattern between June and September. Although the sum of the contents of hydroxycinnamic acids and flavonols was the highest in June, the sum of the contents of flavan-3-ols overshadowed the contents of other phenolic compounds. In the case of fruit phenolics: the sum of the contents of hydroxycinnamic acids, flavonols, and flavan-3-ols was the highest in early August, while the sum of the contents of flavones and anthocyanins was the highest in mid-September. According to our results, the highest content of different classes of phenolics was in relatively young fruit, which decreased steadily during growth. A similar decrease was reported in apple [Burda et al., 1990], peach [Lee et al., 1990], grape [Romeyer et al., 1983], and loquat fruit [Ding et al., 2001]. Seasonal decrease in phenolics content may be due to their conversion into insoluble cell wall components, or transformation into oligo and polymeric compounds, e.g. tannins or lignans [Nurmi et al., 1996]. 
TABLE 1. Total phenolics (TP) content and the antioxidant activity of extracts from C. pentagyna Willd. flowers, fruits, and leaves represented as mean \pm standard deviation (SD).

\begin{tabular}{|c|c|c|c|c|c|c|}
\hline \multirow{2}{*}{ Harvest date } & \multirow{2}{*}{ Sample } & TP content & DPPH assay & ABTS assay & CUPRAC assay & FRP assay \\
\hline & & (mg GAE/g dry weight) & \multicolumn{4}{|c|}{ ( $\mu$ mol TE/g dry weight) } \\
\hline 19th May & \multirow[t]{3}{*}{ Flowers } & $84.5 \pm 1.2$ & $466 \pm 10$ & $477 \pm 2$ & $579 \pm 5$ & $311 \pm 2$ \\
\hline 19th May & & $85.7 \pm 1.1^{\mathrm{e}^{*}}$ & $499 \pm 5^{\mathrm{d}}$ & $485 \pm 1^{\mathrm{e}}$ & $580 \pm 5^{\mathrm{d}}$ & $438 \pm 5^{\mathrm{e}}$ \\
\hline 10th June & & $89.4 \pm 1.5^{\mathrm{d}}$ & $533 \pm 5^{\mathrm{cd}}$ & $507 \pm 3^{\mathrm{d}}$ & $670 \pm 5^{\mathrm{d}}$ & $486 \pm 5^{\mathrm{d}}$ \\
\hline 13th July & \multirow[t]{4}{*}{ Leaves } & $98.3 \pm 0.5^{\mathrm{c}}$ & $570 \pm 8^{\mathrm{bc}}$ & $562 \pm 5^{\mathrm{c}}$ & $690 \pm 5^{c}$ & $527 \pm 3^{\mathrm{c}}$ \\
\hline 5th August & & $107 \pm 2^{\mathrm{b}}$ & $612 \pm 12^{b}$ & $579 \pm 5^{b}$ & $705 \pm 5^{\mathrm{b}}$ & $621 \pm 2^{b}$ \\
\hline \multirow[t]{2}{*}{ 16th September } & & $128 \pm 1^{\mathrm{a}}$ & $749 \pm 5^{\mathrm{a}}$ & $641 \pm 2^{\mathrm{a}}$ & $760 \pm 2^{\mathrm{a}}$ & $668 \pm 3^{\mathrm{a}}$ \\
\hline & & (mg GAE/g fresh weigh) & \multicolumn{4}{|c|}{ ( $\mu \mathrm{mol} \mathrm{TE} / \mathrm{g}$ fresh weight) } \\
\hline 13th July & \multirow{4}{*}{ Fruits } & $36.7 \pm 0.5^{\mathrm{c}}$ & $14.6 \pm 0.2^{\mathrm{d}}$ & $26.4 \pm 0.2^{\mathrm{c}}$ & $50.3 \pm 1.4^{\mathrm{a}}$ & $33.8 \pm 0.6^{\mathrm{c}}$ \\
\hline 5th August & & $45.1 \pm 0.6^{b}$ & $19.7 \pm 0.1^{\mathrm{c}}$ & $28.9 \pm 0.1^{\mathrm{b}}$ & $58.1 \pm 0.5^{\mathrm{a}}$ & $61.1 \pm 0.6^{\mathrm{b}}$ \\
\hline 16th September & & $45.9 \pm 0.9^{\mathrm{b}}$ & $20.1 \pm 0.1^{\mathrm{b}}$ & $28.8 \pm 0.1^{\mathrm{b}}$ & $70.0 \pm 0.3^{\mathrm{a}}$ & $113 \pm 6^{\mathrm{a}}$ \\
\hline 10th October & & $53.8 \pm 0.5^{\mathrm{a}}$ & $21.1 \pm 0.1^{\mathrm{a}}$ & $30.7 \pm 0.2^{\mathrm{a}}$ & $72.0 \pm 0.3^{\mathrm{a}}$ & $109 \pm 2^{\mathrm{a}}$ \\
\hline
\end{tabular}

* Values for leaves or fruits in the same column with different superscripts $(\mathrm{a}-\mathrm{e})$ are significantly different $(\mathrm{p}<0.05)$ based on the analysis of variance and Tukey's test.

According to our results, the highest content of different classes of phenolics was found in leaves harvested at the early maturity stage (Table 3), while the total phenolics content was the highest in leaves harvested at the end of the growing season (Table 1). If we look at other studies, there are some opposed claims. According to Wang \& Lin [2000], young leaves from blackberry, raspberry, and strawberry had a higher content of total phenolics than mature leaves. Similarly to our results, Vaigiri et al. [2015] found that young leaves do not always express a higher content of total phenolics, compared to mature leaves. Also, the sum of contents of phenolic compounds was lower than the content of total phenolics determined using the method with the Folin-Ciocalteu's phenol reagent, which is understandable. The Folin-Ciocalteu's method is less selective and specific (as the reagent is reacting not merely with phenolics but with some nitrogen-containing compounds) and tends to overestimate the content of total phenolics. In addition, there might be some high molecular weight phenolic compounds in hawthorn extracts, which can react with the reagent. Gao et al. [2010] identified seven lignin-glycosides in the leaves of $C$. pinnatifida. Amel et al. [2014] found that total tannins content in the leaves of $C$. azarolus $(115.33 \mathrm{mg} / \mathrm{g}$, expressed as tannic acid equivalents) was comparable to total phenolics content $(188.91 \mathrm{mg} / \mathrm{g}$, expressed as gallic acid equivalents). Both, lignans and tannins are high molecular weight polymers, containing aromatic hydroxyl groups that react with the Folin-Ciocalteu's phenol reagent, hence discrepancies between the content of total phenolics and the sum of phenolics can be explained in this manner.

\section{Antioxidant activity}

A substantial number of reactive chemical species with various mechanisms of action can damage the homeostasis of the cell [Cecarini et al., 2007]. Because of that, it is im- possible to define one method for determining antioxidant activity, and it is necessary to choose a combination of several tests based on different principles to demonstrate the antioxidative potential through various mechanisms of action such as direct bonding of free radicals, electron transfer, inhibition of prooxidative enzymes, activating antioxidant enzymes, chelating of prooxidative metal ions etc. [Huang et al., 2005]. The results of different antioxidant activity assays are presented in Table 1. Results from this study showed that the antioxidant activities follow the clear pattern: throughout the harvest season, there is an evident increase of antioxidant activity with an increase in the total phenolics content.

\section{Variation in the content of individual phenolic compounds during harvesting period}

Twenty-two compounds belonging to five groups of phenolic compounds (hydroxycinnamic acids, flavonols, flavones, flavan-3-ols, and anthocyanins) were detected and identified or tentatively identified in flowers, fruits, and leaves of $C$. pentagyna Willd. Their contents are presented in Table 2 and 3.

Hydroxycinnamic acids were the major phenolic compounds in the flower $(13.3 \mathrm{mg} / \mathrm{g}$ dry weight), and accounted for $64.5 \%$ of the total phenolic compounds $(20.6 \mathrm{mg} / \mathrm{g}$ dry weight). Isomeric acids, neochlorogenic (5-O-caffeoylquinic acid) and chlorogenic (3-O-caffeoylquinic acid), were the most abundant in flowers $(5.20$ and $4.85 \mathrm{mg} / \mathrm{g}$ dry weight, respectively). Compared with the content of hydroxycinnamic acids, the content of flavan-3-ols was quite low $(2.02 \mathrm{mg} / \mathrm{g}$ dry weight). (-)-Epicatechin was the most abundant flavan-3 -ol ( $1.54 \mathrm{mg} / \mathrm{g}$ dry weight), which accounted for $76 \%$ of total flavan-3-ols. Similar results were reported for the content of (-)-epicatechin in flowers of $C$. laevigata, lower ones for the flowers of $C$. pinnatifida var. major [Chen \& Liu, 2005], and higher ones for the flowers of C. monogyna [Bernato- 
TABLE 2. The content of hydroxycinnamic acids, flavonols, flavones, anthocyanins, and flavan-3-ols in flowers (mg/g dry weight) and fruit (mg/g fresh weight) of $C$. pentagyna Willd. at different harvest times.

\begin{tabular}{|c|c|c|c|c|c|}
\hline \multirow{3}{*}{ Phenolic compounds } & \multicolumn{5}{|c|}{ Harvest date } \\
\hline & $19^{\text {th }}$ May & $13^{\text {th }}$ July & $5^{\text {th }}$ August & $16^{\text {th }}$ September & $6^{\text {th }}$ October \\
\hline & Flowers & \multicolumn{4}{|c|}{ Fruits } \\
\hline Neochlorogenic acid & $5.20 \pm 0.30$ & - & - & - & - \\
\hline Caffeic acid & $1.01 \pm 0.02$ & $0.45 \pm 0.01^{\mathrm{b}^{*}}$ & $1.13 \pm 0.01^{\mathrm{a}}$ & $0.14 \pm 0.01^{\mathrm{d}}$ & $0.23 \pm 0.01^{c}$ \\
\hline Chlorogenic Acid & $4.85 \pm 0.03$ & $0.10 \pm 0.01^{\mathrm{d}}$ & $1.21 \pm 0.02^{\mathrm{b}}$ & $1.52 \pm 0.01^{\mathrm{a}}$ & $0.84 \pm 0.02^{c}$ \\
\hline 4- $O$-Caffeoylquinic acid & $1.24 \pm 0.05$ & - & - & $0.45 \pm 0.02^{\mathrm{a}}$ & $0.46 \pm 0.01^{\mathrm{a}}$ \\
\hline 4-O-p-Coumaroylquinic acid & - & $0.041 \pm 0.001^{\mathrm{d}}$ & $0.061 \pm 0.004^{c}$ & $0.17 \pm 0.01^{\mathrm{b}}$ & $0.24 \pm 0.01^{\mathrm{a}}$ \\
\hline$p$-Coumaric acid & $1.01 \pm 0.03$ & $0.020 \pm 0.001$ & - & - & - \\
\hline Ferulic acid & - & $1.16 \pm 0.01^{\mathrm{a}}$ & $0.85 \pm 0.02^{\mathrm{b}}$ & $0.41 \pm 0.01^{\mathrm{c}}$ & - \\
\hline$\sum$ Hydroxycinnamic acids & 13.3 & $1.78 \pm 0.01^{c}$ & $3.26 \pm 0.04^{a}$ & $2.69 \pm 0.03^{b}$ & $1.77 \pm 0.04$ \\
\hline Rutin & $0.50 \pm 0.01$ & $0.140 \pm 0.001^{\mathrm{c}}$ & $0.078 \pm 0.002^{\mathrm{d}}$ & $0.18 \pm 0.01^{\mathrm{b}}$ & $0.22 \pm 0.01^{\mathrm{a}}$ \\
\hline Hyperoside & $0.46 \pm 0.01$ & $1.12 \pm 0.03^{b}$ & $1.54 \pm 0.03^{\mathrm{a}}$ & $0.75 \pm 0.02^{\mathrm{c}}$ & $0.74 \pm 0.04^{c}$ \\
\hline Isoquercetin & $3.14 \pm 0.05$ & $0.21 \pm 0.02^{\mathrm{d}}$ & $0.47 \pm 0.01^{\mathrm{c}}$ & $0.61 \pm 0.01^{\mathrm{b}}$ & $0.64 \pm 0.01^{\mathrm{a}}$ \\
\hline Quercetin pentoside & - & $0.059 \pm 0.001^{\mathrm{a}}$ & $0.019 \pm 0.001^{\mathrm{c}}$ & $0.030 \pm 0.001^{\mathrm{b}}$ & - \\
\hline Kaempferol rutinoside & $0.17 \pm 0.02$ & - & - & - & - \\
\hline Quercetin rhamnoside & $0.09 \pm 0.00$ & - & - & - & - \\
\hline Quercetin & - & - & - & - & - \\
\hline Kaempferol & $0.07 \pm 0.00$ & - & - & - & - \\
\hline$\sum$ Flavonols & 4.27 & $1.53 \pm 0.03^{\text {bc }}$ & $2.11 \pm 0.02^{a}$ & $1.57 \pm 0.02^{b, c}$ & $1.60 \pm 0.05^{b}$ \\
\hline Luteolin glycoside & $0.31 \pm 0.02$ & $0.050 \pm 0.002^{\mathrm{d}}$ & $0.060 \pm 0.001^{\mathrm{b}}$ & $0.090 \pm 0.001^{\mathrm{a}}$ & $0.060 \pm 0.001^{\mathrm{b}}$ \\
\hline Apigenin glycoside & $0.74 \pm 0.04$ & $0.12 \pm 0.01^{\mathrm{c}}$ & $0.060 \pm 0.002^{\mathrm{d}}$ & $0.23 \pm 0.02^{\mathrm{a}}$ & $0.19 \pm 0.01^{\mathrm{b}}$ \\
\hline$\sum$ Flavones & 1.05 & $0.17 \pm 0.01^{c}$ & $0.120 \pm 0.0033^{d}$ & $0.32 \pm 0.02^{\mathrm{a}}$ & $0.25 \pm 0.01^{b}$ \\
\hline PC derivative & - & $0.47 \pm 0.01^{\mathrm{c}}$ & $0.32 \pm 0.01^{\mathrm{d}}$ & $2.27 \pm 0.02^{\mathrm{a}}$ & $0.77 \pm 0.03^{b}$ \\
\hline Procyanidin B2 & $0.48 \pm 0.02$ & $2.68 \pm 0.03^{c}$ & $9.01 \pm 0.02^{b}$ & $10.6 \pm 0.1^{\mathrm{a}}$ & $9.05 \pm 0.01^{b}$ \\
\hline (-)-Epicatechin & $1.54 \pm 0.08$ & $6.29 \pm 0.02^{\mathrm{d}}$ & $21.1 \pm 0.1^{\mathrm{a}}$ & $13.1 \pm 0.1^{\mathrm{c}}$ & $14.3 \pm 0.2^{b}$ \\
\hline Procyanidin B5 & - & $0.75 \pm 0.01^{\mathrm{d}}$ & $1.17 \pm 0.02^{\mathrm{c}}$ & $3.74 \pm 0.06^{\mathrm{a}}$ & $2.65 \pm 0.02^{\mathrm{b}}$ \\
\hline$\sum$ Flavan-3-ols (monomer + dimers) & 2.02 & $10.2 \pm 0.1^{\mathrm{d}}$ & $31.6 \pm 0.1^{\mathrm{a}}$ & $29.7 \pm 0.1^{b}$ & $26.8 \pm 0.2^{c}$ \\
\hline Ideain & - & $0.32 \pm 0.02^{\mathrm{d}}$ & $0.67 \pm 0.02^{\mathrm{c}}$ & $4.70 \pm 0.05^{\mathrm{b}}$ & $6.21 \pm 0.04^{\mathrm{a}}$ \\
\hline$\sum$ Anthocyanins & - & $0.32 \pm 0.02^{\mathrm{d}}$ & $0.67 \pm 0.02^{c}$ & $4.70 \pm 0.05^{b}$ & $6.21 \pm 0.04^{\mathrm{a}}$ \\
\hline$\sum$ Indiv. phenolics & 20.6 & $14.0 \pm 0.1^{\mathrm{d}}$ & $37.7 \pm 0.1^{b}$ & $39.1 \pm 0.2^{\mathrm{a}}$ & $36.6 \pm 0.2^{c}$ \\
\hline
\end{tabular}

*Values for leaves or fruits in the same row with different superscripts $(\mathrm{a}-\mathrm{d})$ are significantly different $(\mathrm{p}<0.05)$ based on the analysis of variance and Tukey's test.

niene et al., 2008]. Isoquercetin, rutin, and hyperoside represented $92.5 \%$ of total flavonols. Isoquercetin was the major flavonol glycoside $(3.14 \mathrm{mg} / \mathrm{g})$ accounting for $70.9 \%$ of total flavonols. According to an extensive literature review, previous studies were mainly focused on the isolation of flavones and flavonols from the $C$. pentagyna. According to Nikolov [1975], besides flavone $C$-monoglycosides (vitexin, saponaretin, orientin, and homoorientin) vitexin rhamnoside was isolated from the $C$. pentagyna. From the leaves and flowers of the $C$. penatgyna $\mathrm{W}$. et K., two flavonol glycosides were isolated: crateside (quercetin 3'- $\beta$-L-arabofuranoside) [Nikolov et al., 1973a] and glogoside (3-O-methylherbacetin-8- $\beta$ -D-glucopyranoside) [Nikolov et al., 1973b]. Besides rutin, various glycosides of vitexin and orientin have been isolated from the leaves and flowers of the $C$. pentagyna, and identified as: 2"-O-rhamnosyl-isovitexin, 2 "- $O$-rhamnosyl-vitexin, 2"-O-rhamnosyl-(4"'-O-acetyl)-vitexin, 2"-O-rhamnosyl-orientin, and 2"-O-rhamnosyl-isoorientin [Nikolov et al., 1982]. 
TABLE 3. The content of hydroxycinnamic acids, flavonols, flavones, anthocyanins, and flavan-3-ols in leaves (mg/g dry weight) of $C$. pentagyna Willd. at different harvest times.

\begin{tabular}{|c|c|c|c|c|c|}
\hline \multirow{2}{*}{ Phenolic compounds } & \multicolumn{5}{|c|}{ Harvest date } \\
\hline & $19^{\text {th }}$ May & $10^{\text {th }}$ June & $13^{\text {th }}$ July & $5^{\text {th }}$ August & $16^{\text {th }}$ September \\
\hline Neochlorogenic acid & $2.26 \pm 0.03^{\mathrm{a}^{\mathrm{x}}}$ & $1.11 \pm 0.05^{\mathrm{b}}$ & $0.39 \pm 0.03^{\mathrm{d}}$ & $0.47 \pm 0.03^{c}$ & $0.15 \pm 0.01^{\mathrm{e}}$ \\
\hline Caffeic acid & $0.65 \pm 0.02^{\mathrm{a}}$ & $0.21 \pm 0.01^{\mathrm{b}}$ & $0.14 \pm 0.01^{\mathrm{c}}$ & $0.14 \pm 0.01^{\mathrm{c}}$ & $0.10 \pm 0.01^{\mathrm{d}}$ \\
\hline Chlorogenic acid & $5.30 \pm 0.20^{\mathrm{a}}$ & $5.03 \pm 0.06^{\mathrm{a}}$ & $1.79 \pm 0.09^{c}$ & $2.18 \pm 0.02^{\mathrm{b}}$ & $1.32 \pm 0.02^{\mathrm{d}}$ \\
\hline 4- $O$-Caffeoylquinic acid & $0.49 \pm 0.01^{\mathrm{a}}$ & $0.44 \pm 0.01^{\mathrm{b}}$ & $0.20 \pm 0.01^{\mathrm{d}}$ & $0.248 \pm 0.002^{\mathrm{c}}$ & $0.12 \pm 0.01^{\mathrm{e}}$ \\
\hline 4-O-p-Coumaroilquinic acid & $0.73 \pm 0.02^{\mathrm{a}}$ & $0.54 \pm 0.01^{\mathrm{b}}$ & $0.078 \pm 0.003^{\mathrm{d}}$ & $0.118 \pm 0.002^{\mathrm{c}}$ & $0.048 \pm 0.003^{\mathrm{e}}$ \\
\hline$p$-Coumaric acid & $1.56 \pm 0.09^{\mathrm{a}}$ & $1.25 \pm 0.04^{\mathrm{b}}$ & $0.57 \pm 0.04^{\mathrm{c}, \mathrm{d}}$ & $0.67 \pm 0.03^{c}$ & $0.45 \pm 0.01^{\mathrm{d}}$ \\
\hline Ferulic acid & $1.13 \pm 0.08^{\mathrm{a}}$ & $0.73 \pm 0.02^{\mathrm{b}}$ & $0.56 \pm 0.05^{\mathrm{c}}$ & $0.39 \pm 0.02^{\mathrm{d}}$ & $0.34 \pm 0.01^{\mathrm{d}}$ \\
\hline$\sum$ Hydroxycinnamic acids & $12.1 \pm 0.3^{a}$ & $9.31 \pm 0.12^{b}$ & $3.74 \pm 0.10^{d}$ & $4.22 \pm 0.06^{c}$ & $2.53 \pm 0.06^{\mathrm{e}}$ \\
\hline Rutin & $1.23 \pm 0.03^{b}$ & $1.00 \pm 0.01^{\mathrm{d}}$ & $1.20 \pm 0.02^{b}$ & $1.46 \pm 0.01^{\mathrm{a}}$ & $1.12 \pm 0.02^{c}$ \\
\hline Hyperoside & $4.54 \pm 0.05^{\mathrm{a}}$ & $3.00 \pm 0.03^{\mathrm{b}}$ & $2.43 \pm 0.01^{\mathrm{d}}$ & $2.15 \pm 0.02^{\mathrm{e}}$ & $2.68 \pm 0.01^{\mathrm{c}}$ \\
\hline Isoquercetin & $0.24 \pm 0.01^{\mathrm{b}}$ & $0.058 \pm 0.002^{\mathrm{e}}$ & $0.26 \pm 0.01^{\mathrm{a}}$ & $0.150 \pm 0.002^{\mathrm{c}}$ & $0.120 \pm 0.005^{\mathrm{d}}$ \\
\hline Quercetin pentoside & $0.53 \pm 0.01$ & - & - & - & - \\
\hline Kaempferol rutinoside & $0.30 \pm 0.01^{\mathrm{a}}$ & $0.14 \pm 0.01^{\mathrm{b}}$ & - & - & - \\
\hline Quercetin rhamnoside & $0.17 \pm 0.01^{\mathrm{c}}$ & $0.049 \pm 0.002^{\mathrm{e}}$ & $0.10 \pm 0.01^{\mathrm{d}}$ & $0.24 \pm 0.01^{\mathrm{b}}$ & $0.49 \pm 0.01^{\mathrm{a}}$ \\
\hline Quercetin & $0.36 \pm 0.00^{\mathrm{b}}$ & $0.45 \pm 0.02^{\mathrm{a}}$ & $0.32 \pm 0.02^{c}$ & $0.01 \pm 0.01^{\mathrm{e}}$ & $0.058 \pm 0.002^{\mathrm{d}}$ \\
\hline Kaempferol & - & - & - & - & - \\
\hline$\sum$ Flavonols & $7.37 \pm 0.09^{a}$ & $4.70 \pm 0.03^{b}$ & $4.31 \pm 0.011^{\mathrm{d}}$ & $4.01 \pm 0.03^{e}$ & $4.47 \pm 0.01^{c}$ \\
\hline Luteolin glycoside & - & - & - & - & $0.089 \pm 0.003$ \\
\hline Apigenin glycoside & $0.030 \pm 0.002^{\mathrm{d}}$ & $0.82 \pm 0.02^{\mathrm{c}}$ & $1.61 \pm 0.01^{\mathrm{a}}$ & $1.46 \pm 0.02^{\mathrm{b}}$ & $1.58 \pm 0.02^{\mathrm{a}}$ \\
\hline$\sum$ Flavones & $0.030 \pm 0.002^{\mathrm{e}}$ & $0.82 \pm 0.011^{d}$ & $1.61 \pm 0.011^{b}$ & $1.46 \pm 0.02^{c}$ & $1.67 \pm 0.02^{a}$ \\
\hline PC derivative & $0.80 \pm 0.02^{\mathrm{d}}$ & $1.90 \pm 0.02^{\mathrm{a}}$ & $1.18 \pm 0.02^{\mathrm{b}}$ & $1.00 \pm 0.07^{\mathrm{c}}$ & $0.99 \pm 0.02^{c}$ \\
\hline Procyanidin B2 & $3.20 \pm 0.01^{\mathrm{c}}$ & $5.88 \pm 0.13^{\mathrm{a}}$ & $3.03 \pm 0.10^{\mathrm{d}}$ & $2.94 \pm 0.02^{\mathrm{d}}$ & $3.60 \pm 0.05^{\mathrm{b}}$ \\
\hline Epicatechin & $9.75 \pm 0.11^{\mathrm{d}}$ & $15.1 \pm 0.1^{\mathrm{a}}$ & $12.7 \pm 0.2^{\mathrm{b}}$ & $11.3 \pm 0.3^{\mathrm{c}}$ & $12.8 \pm 0.2^{\mathrm{b}}$ \\
\hline Procyanidin B5 & $2.20 \pm 0.01^{\mathrm{bc}}$ & $3.92 \pm 0.08^{\mathrm{a}}$ & $2.03 \pm 0.03^{\mathrm{c}}$ & $2.31 \pm 0.09^{\mathrm{b}}$ & $0.53 \pm 0.04^{\mathrm{d}}$ \\
\hline$\sum$ Flavan-3-ols (monomer + dimers) & $15.9 \pm 0.1^{d}$ & $26.8 \pm 0.3^{a}$ & $18.9 \pm 0.3^{b}$ & $17.6 \pm 0.3^{c}$ & $18.0 \pm 0.2^{c}$ \\
\hline$\sum$ Indiv. phenolics & $35.5 \pm 0.4^{b}$ & $41.6 \pm 0.4^{\mathrm{a}}$ & $28.6 \pm 0.4^{c}$ & $27.3 \pm 0.3^{\mathrm{d}}$ & $26.6 \pm 0.3^{d}$ \\
\hline
\end{tabular}

*Values for leaves or fruits in the same row with different superscripts (a-e) are significantly different $(\mathrm{p}<0.05)$ based on the analysis of variance and Tukey's test.

According to Prinz et al. [2007], vitexin, isovitexin, rutin, hyperoside, and isoquercitrin are the compounds which can be found in C. pentagyna, C. monogyna as well in C. laevigata., while isoorientin, isoquercitrin, and 8-methoxykaempferol3-O-glucoside were found only in $C$. pentagyna and could serve as markers for the differentiation of $C$. pentagyna from C. monogyna and $C$. laevigata.

Procyanidins B2 and B5 showed similar changing trends during the harvest period. The highest contents of procyanidins B2 and B5 were found in the fruits collected in September (10.6 and $3.74 \mathrm{mg} / \mathrm{g}$ fresh weight, respectively); their contents were observed to increase successively from July. From mid-September, the content of procyanidins decreased.
Monomers and dimers of flavan-3-ols were the major phenolic compounds in the fruits of $C$. pentagyna Willd (Table 2). The sum of the contents of flavan-3-ols varied from 10.2 to $29.7 \mathrm{mg} / \mathrm{g}$ fresh weight during the harvest period. (-)-Epicatechin $(6.29-21.1 \mathrm{mg} / \mathrm{g}$ fresh weight) and procyanidin B2 (2.68-10.6 mg/g fresh weight) were the most abundant. Ideain (cyanidin 3-O-galactoside) was the second most abundant phenolic compound in fruits, and its content increased from 0.32 to $6.21 \mathrm{mg} / \mathrm{g}$ fresh weight during the growing season. Compared to the contents of flavan-3-ols, those of hydroxycinnamic acids and flavonols were quite low. The major flavonols were hyperoside and isoquercetin. Chlorogenic acid was the most abundant hydroxycinnamic acid with content rang- 
ing from 0.10 to $1.52 \mathrm{mg} / \mathrm{g}$ fresh weight. On the other hand, (-)-epicatechin content was at the highest level in August (21.1 mg/g fresh weight). Afterwards, it decreased dramatically. Chlorogenic and caffeic acids displayed quite similar changing trends during the harvest period. The highest contents of those acids were found in the fruits collected in August and September, which is consistent with fruit ripening season (August-October). The content of hyperoside, which is the most abundant flavonol glycoside, was the highest in August and afterwards it decreased by 50\%. In most cases, the contents of flavonol glycosides were the highest in early stages of fruit development. Similar behavior of flavonol glycosides was detected in apples [Awad et al., 2001] and blueberries [Jaakola et al., 2002]. With the exception of ideain, the majority of phenolic compounds in fruits of $C$. pentagyna Willd. reached the highest content in August and September. The content of ideain in fruits increased continuously throughout the harvest period $(0.32-6.21 \mathrm{mg} / \mathrm{g}$ fresh weight). Similar results were reported earlier in other hawthorn species and fruit [Elmastas et al., 2017; Jaakola et al., 2002]. There is evidence that the flavonoid biosynthesis is closely related to the stage of fruit development and that the activity of the enzyme is controlled due to diverse ecological and developmental conditions [Jaakola et al., 2002]. During the development of blueberry fruit (Vaccinium myrtillus), studying the expression of five genes involved in the flavonoid biosynthesis, Jaakola et al. [2002] concluded the following: coordinated expression of the genes involved in the flavonoid biosynthesis influences the accumulation of flavonols, proanthocyanidins, and anthocyanins during fetal development. As well, expression of these genes occurs in two phases: during the flowering stage and earlier stages of ripening when the color of fruit steel develops. Gene expression is most pronounced in the ripening stage when the fruit is still immature from the inside, with certain colored stains and then in the fully mature fruit the expression of the gene is declining. Similar enzymatic activities were also observed by Manning [1998] during the development of strawberry fruit and by Kobayashi et al. [2001] during the development of grapes.

The sum of flavan-3-ols in the leaves ranged from 16 to $26.8 \mathrm{mg} / \mathrm{g}$ dry weight (Table 3). As in the fruits, (-)-epicatechin, procyanidin B2, and procyanidin B5 were the major flavan3-ols. Hydroxycinnamic acids were the second most abundant compounds. Chlorogenic, neochlorogenic, $p$-coumaric, and ferulic acids were present at 5.30, 2.26, 1.56, and $1.13 \mathrm{mg} / \mathrm{g}$ dry weight, respectively, at the beginning of the harvest period. The content of hyperoside, the most abundant flavonol glycoside (4.54-2.68 mg/g dry weight), decreased from May to August, and then slightly increased in September. This increase in the content of hyperoside may be related to a drop in temperature [He et al., 2016].

The changing patterns for hydroxycinnamic acids were quite similar: at the beginning of the harvest period (May) the content of all hydroxycinnamic acids was at the highest level, and decreased until July. Afterwards, the content of individual hydroxycinnamic acids fluctuated: content of individual hydroxycinnamic acids remained constant or slightly increased in August and decreased after that. Flavan-3-ol contents of leaves increased progressively from May until reaching the highest levels in June. Afterwards, it decreased until August, and slightly increased in September. A literature review indicates that phenolic composition of plant tissue is determined by many factors, such as genotype, ontogenesis, environment, stage of the development, analysis time, processing and storage conditions, as well as the method of analysis itself [Krüger et al., 2011; Martz et al., 2010].

One-way ANOVA was used in order to examine the effect of harvesting date on total phenolic content, content of individual phenolics, and the sum of the contents of phenolic compounds belonging to different classes in fruits and leaves of $C$. pentagyna Willd. The results of Tukey's HSD test (confidence interval $95 \%, \mathrm{p}<0.05$ ), which was used to show a significant difference in the content of the total pheholics, individual phenolic compounds, the sum of the contents of different classes of phenolics, and the antioxidant activity in fruits and leaves harvested in different periods, are represented in Table 1, 2, and 3.

The coefficient of determination $\left(\mathrm{R}^{2}=0.997\right)$ has shown that $99.7 \%$ of the variability of the total phenolics content in the $C$. pentagyna Willd. leaves is being explained by the explanatory variables (harvest period). According to the results of the Tukey's HSD test, we have concluded with confidence that there is a significant effect of the harvesting date on the total phenolics content in the leaves of $C$. pentagyna Willd (Table 1). The ANOVA results for the effect of the harvesting date on the antioxidant activity of leaves, measured by DPPH $\left(\mathrm{R}^{2}=0.984\right)$, ABTS $\left(\mathrm{R}^{2}=0.997\right)$, CUPRAC $\left(\mathrm{R}^{2}=0.997\right)$, and FRP $\left(\mathrm{R}^{2}=0.998\right)$ have shown that there was a significant difference in the antioxidant activity in different harvesting periods (Table 1). Same results were obtained for the effect of harvest date on the content of individual phenolics and the sum of the contents of different classes of phenolics in the leaves. The coefficient of determination $\left(\mathrm{R}^{2}\right)$ ranged from 0.984 to 0.999 for different quantitative variables (content of individual phenolics and the sum of the content of the different classes of phenolics) so the $98.4 \%-99.9 \%$ of the variability in the content of individual phenolics and the sum of the content of different classes has been explained by the harvest period (Table 3). Similarly, ANOVA results for the total phenolics content, the antioxidant activity, and the content of individual phenolics in fruits have shown a significant effect of the harvest date (Table 2).

\section{Correlation analysis}

Correlation analysis was used to explore the relationships amongst the sum of the contents of phenolic compounds belonging to individual classes and the antioxidant activity determined by different assays for fruits and leaves of $C$. pentagyna Willd. Pearson's correlation coefficients are represented in Table 4.

Based on the Pearson's correlation coefficients, it is clear that for fruit samples there are direct correlations between the total flavone content and the antioxidant activities determined particularly with CUPRAC $(r=0.769)$ and FRP $(r=0.825)$ methods. Flavan-3-ol content showed a significant simple correlation with the antioxidant activity determined by the ABTS method $(r=0.761)$, as well as a very strong correlation with the antioxidant activity determined by the DPPH 
TABLE 4. Pearson's correlation coefficient (r) between: $\sum$ hydroxycinnamic acids, $\sum$ flavonols, $\sum$ flavones, $\sum$ flavan-3-ols, and $\sum$ anthocyanin, total phenolic content (TPC) and antioxidant activity determined with DPPH, ABTS, CUPRAC, and FRP assays in fruits and leaves of $C$. pentagyna Willd.

\begin{tabular}{|c|c|c|c|c|c|c|c|c|c|c|}
\hline & \multicolumn{5}{|c|}{ Leaves } & \multicolumn{5}{|c|}{ Fruits } \\
\hline & TPC & DPPH & ABTS & CUPRAC & FRP & $\mathrm{TPC}$ & DPPH & ABTS & CUPRAC & FRP \\
\hline$\sum$ Hydroxycinnamic acids & $0.827 *$ & -0.810 & -0.928 & -0.916 & -0.879 & 0.005 & 0.368 & 0.100 & 0.008 & 0.046 \\
\hline$\sum$ Flavonols & -0.543 & -0.549 & -0.671 & -0.860 & -0.701 & 0.079 & 0.286 & 0.180 & -0.193 & -0.228 \\
\hline$\sum$ Flavones & $\mathbf{0 . 7 5 3}$ & 0.746 & 0.871 & 0.928 & $\mathbf{0 . 8 2 8}$ & 0.415 & 0.417 & 0.354 & 0.769 & 0.825 \\
\hline$\sum$ Flavan-3-ols & -0.297 & 0.023 & 0.028 & 0.397 & 0.074 & 0.703 & 0.919 & 0.761 & 0.682 & 0.677 \\
\hline$\sum$ Anthocyanins & & & & & & 0.843 & $\mathbf{0 . 7 3 3}$ & 0.792 & 0.956 & 0.939 \\
\hline
\end{tabular}

*Values in bold refer to statistically significant correlations at $\mathrm{p}<0.05$

method $(r=0.919)$. The content of anthocyanins was well correlated with the antioxidant activity of the fruit when assayed with all methods $(r=0.733-0.956)$. The best correlation was found between the content of ideain in the fruit and the antioxidant activity determined with the CUPRAC method $(r=0.956)$. A weak correlation between the sum of the contents of hydroxycinnamic acids, flavonols, and the antioxidant activity of the fruit could be the consequence of the structure of the phenolic compounds themselves since only the flavonoids of the certain structure and the exact position of the $\mathrm{OH}$ group in the molecule determine the antioxidant properties [Heim et al., 2002]. Both the configuration and the total number of hydroxyl groups substantially influence the mechanism of the antioxidant activity. The glycosylation of flavonoids reduces their in vitro antioxidant activity when compared to the corresponding aglycons [Rice-Evans et al., 1996; Mishra et al., 2003]. For example, the comparison of TEAC values of quercetin and rutin (quercetin 3-O-rutinoside), shows that glycosylation of the 3-OH group has a strong suppressive effect on the antioxidant activity [Rice-Evans et al, 1996]. Similar results were observed for other pairs of flavonoid aglycon and glycoside (hesperetin - hesperidin, luteolin - luteolin-4'-glucoside; luteolin - luteolin-7-glucoside; quercetin - quercitrin) [Rice-Evans et al., 1996] also. Based on these results, we can say that flavones contribute most to the antioxidant activity determined with the FRP method, the flavan-3-ols to the antioxidant activity determined with the DPPH method, and the anthocyanins to the antioxidant activity determined with the CUPRAC method. As flavan-3-ols ((-)-epicatechin as the most preferred flavan-3-ol) and ideaine are the most abundant compounds in the fruit during the entire harvesting period, it can be expected that they contribute most to the antioxidant activity. Unlike the fruit, in which no correlation between the sum of the contents of hydroxycinnamic acids, flavonols and antioxidant activity was observed, with leaf an inverse correlation was noticed between the sum of the contents of hydroxycinnamic acids and antioxidant activity. Content of hydroxycinnamic acids in the leaf showed strong negative correlation with the antioxidant activity determined with all methods ( $\mathrm{r}=-0.810$ to -0.928 ), while flavonols showed a strong correlation with the antioxidant activity determined with CUPRAC $(r=-0.860)$ and FRP $(r=-0.701)$ methods. The sum of the contents of hydroxycinnamic acids and flavonols decreased during the harvest period, and this could be the consequence of the strong negative correlation with antioxidant activity since the antioxidant activity increased during the harvest period. Hence, it might be inferred that hydroxycinnamic acids and flavonols have no impact on the antioxidant activity. Only flavones showed a positive correlation with the antioxidant activity of the leaf $(r=0.746-0.928)$.

A strong correlation was observed between the total phenolics content and the sum of the contents of anthocyanins $(r=0.843)$ and flavan-3-ols $(r=0.703)$ in fruits (Table 4). Based on the obtained results, the strong correlation between these two classes of phenolic compounds and total phenolics content, may be due to the fact that the compounds from those two classes are the predominant related to other compounds. A strong simple correlation between total phenolics content and the sum of the contents of flavones $(r=0.753)$ and a strong negative correlation between total phenolics content and the sum of the contents of hydroxycinnamic acids $(r=-0.827)$ were observed in the case of leaves.

\section{Principal Component Analysis}

PCA was conducted in order to explain the relationship between different conditions, in this case: harvest period, the variation in the sum of the contents of the different classes of phenolic compounds and the antioxidant activity of $C$. pentagyna Willd. leaves and fruits. Factor loadings $>0.90$ are typically regarded as excellent and $<0.7$ as very poor [Gucia et al., 2012]. In this study, three principal components with eigenvalues higher than 1.0 were extracted, as suggested by the Kaiser criterion [1960]. The number of principal components, initial eigenvalues, total variance (percent), and factor loadings are presented in Table 5.

The results of PCA for data sets indicate that three factors explained approximately $96 \%$ of the total variance in the fruits and $98.7 \%$ of the total variance in leaves. The results of the principal component analysis conducted for fruits and leaves are represented in Figure 1A and 1B. Due to a large number of variables compared to the number of samples, the components PC1 and PC2 explained about $87 \%$ and $94 \%$ of the variability of the fruit and leaves samples, respectively. Distinct grouping of the fruit (HF3 and HF4 HF represents hawthorn fruit samples) samples in the lower right quadrant along with the sum of the content of the anthocyanins, as well as the leaves (HL3, HL4, and HL5 - HL represents hawthorn leaves samples) samples with the sum 
TABLE 5. Principal components and factor loadings for the $\sum$ hydroxycinnamic acids, $\sum$ flavonols, $\sum$ flavones, $\sum$ anthocyanins, $\sum$ flavan-3-ols and result of antioxidative assays in fruits and leaves of $C$. pentagyna Willd.

\begin{tabular}{|c|c|c|c|c|c|c|}
\hline & \multicolumn{3}{|c|}{ Fruits } & \multicolumn{3}{|c|}{ Leaves } \\
\hline & PC 1 & PC 2 & PC 3 & PC 1 & PC 2 & PC 3 \\
\hline$\sum$ Hydroxycinnamic acids & $-0.976 *$ & 0.178 & -0.082 & -0.968 & 0.032 & 0.228 \\
\hline$\sum$ Flavonols & -0.072 & 0.984 & 0.117 & -0.832 & -0.488 & 0.237 \\
\hline$\sum$ Flavones & 0.716 & -0.633 & -0.095 & 0.954 & 0.152 & -0.240 \\
\hline$\sum$ Flavan-3-ols & 0.769 & 0.560 & 0.072 & -0.098 & 0.958 & 0.269 \\
\hline$\sum$ Anthocyanins & 0.908 & -0.354 & 0.067 & & & \\
\hline DPPH & 0.925 & 0.358 & 0.118 & 0.892 & -0.236 & 0.375 \\
\hline ABTS & 0.889 & 0.270 & 0.156 & 0.968 & -0.218 & 0.101 \\
\hline CUPRAC & -0.516 & -0.324 & 0.790 & 0.978 & 0.163 & 0.124 \\
\hline FRP & 0.979 & -0.169 & 0.041 & 0.950 & -0.172 & 0.127 \\
\hline Eigenvalue & 5.762 & 2.198 & 0.703 & 6.140 & 1.338 & 0.420 \\
\hline Total variance (\%) & 64.023 & 24.420 & 7.805 & 76.746 & 16.727 & 5.253 \\
\hline Cumulative (\%) & 64.023 & 88.442 & 96.247 & 76.746 & 93.473 & 98.726 \\
\hline
\end{tabular}

*Values in bold refer to statistically significant correlations at $\mathrm{p}<0.05$.

of the content of the flavones is noticeable. PC2 is highly correlated with the sum of the contents of flavonols in the fruit and the sum of the contents of flavan-3-ols in leaves samples. PC1 is strongly correlated with the sum of the contents of flavones and anthocyanins and strongly negatively correlated with the sum of the contents of flavonols and the sum of the contents of hydroxycinnamic acids in leaf samples. Variability in the contents of phenolic compounds during harvesting period can be a consequence of different tissue, growing and environmental conditions or changes in the metabolism of phenolic compounds [Francini \& Sebastiani, 2013].
From the PCA graphs (Figure 1) it can be concluded that PC1 of fruit samples is highly correlated with DPPH, FRP, and ABTS, as well as that FRP and the sum of the contents of anthocyanins are well correlated. It can be assumed that flavan-3-ols and anthocyanins in fruits, as well the later harvest period (HF3 and HF4), have the major effect on the antioxidant activity of $C$. pentagyna Willd. fruits.

In the leaves, flavones as well as antioxidant activity assayed with FRP, DPPH, CUPRAC, and ABTS, are highly correlated with $\mathrm{PC} 1$. The grouping of HL3 along with the CUPRAC and flavones, and HL4 and HL5 in the vicinity of FRP
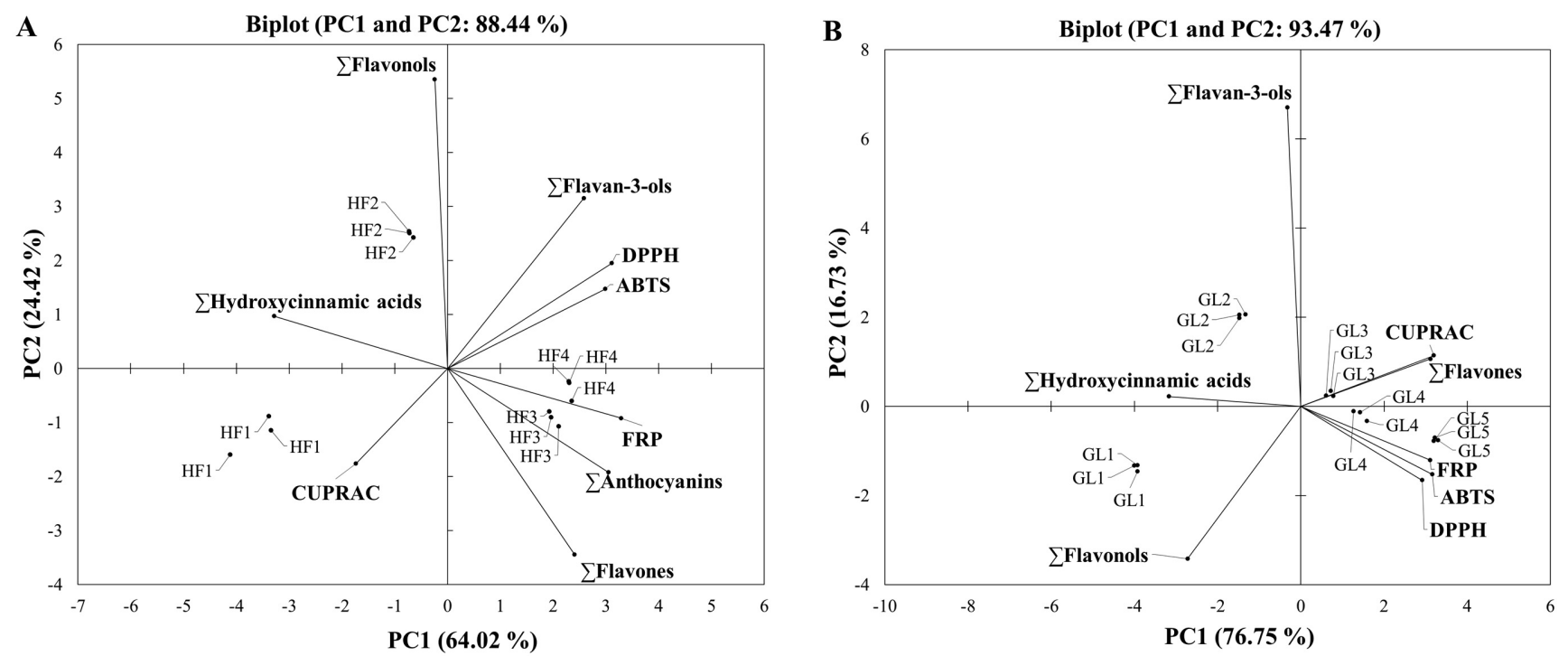

FIGURE 1. Principal component analysis of hawthorn: A) fruits and B) leaves harvested in different periods.

HF* $1-4$ hawthorn fruits harvesting date: $13^{\text {th }}$ July, $5^{\text {th }}$ August, $16^{\text {th }}$ September, $6^{\text {th }}$ October, respectively; HL* $1-5$ hawthorn leaves harvesting date: $19^{\text {th }}$ May, $10^{\text {th }}$ June, $13^{\text {th }}$ July, $5^{\text {th }}$ August, $16^{\text {th }}$ September, respectively. 
is noticeable. Also, flavonols and hydroxycinnamic acids are negatively correlated with PC1, as well as with DPPH, ABTS, and FRP. Flavones and later harvest period (HL3, HL4, and HL5) could be the most meritorious for the antioxidant activity of leaves.

\section{CONCLUSION}

Relying on the results of this research, especially on the content of the individual phenolic compounds in the flowers, leaves, and fruits of $C$. pentagyna Willd., it can be inferred that this study contributes to the better understanding of the influence of different harvest periods on the composition of phenolics within different parts of $C$. pentagyna Willd. plant. As the results of the study show, it can be concluded that there is a seasonal variation in both the quantity and the type of phenolic compounds, which might be due to fluctuations in temperature, precipitation, and conditions of plant habitat. The present work can be useful in finding the appropriate growth conditions and harvest time of $C$. pentagyna Willd. to ensure desired contents of particular valuable compounds.

\section{RESEARCH FUNDING}

The research was financed by the Ministry of Education and Science, the Republic of Serbia, projects No. TR 31060 and 45022 internal macro project of Faculty of Sciences and Mathematics, Kosovska Mitrovica.

\section{REFERENCES}

1. Albarouki, E., Peterson, A. (2007). Molecular and morphological characterization of Crataegus L. species (Rosaceae) in southern Syria. Botanical Journal of the Linnean Society, 153(3), 255-263.

2. Amel, B., Seddik, K., Shtaywy, A., Saliha, D., Mussa, A.Z., Assia, B., Saliha, D., Abderahmane, B., Smain, A. (2014). Phytochemical analysis, antioxidant activity and hypotensive effect of Algerian azarole (Crataegus azarolus L.) leaves extracts. Research Journal of Pharmaceutical, Biological and Chemical Science, 5(2), 286-305.

3. Amira el, A., Behija, S.E., Beligh, M., Lamia, L., Manel, I., Mohamed, H., Lotfi, A. (2012). Effects of the ripening stage on phenolic profile, phytochemical composition and antioxidant activity of date palm fruit. Journal of Agricultural and Food Chemistry, 60(44), 10896-10902.

4. Apak, R., Güçlü, K., Özyürek, M., Karademir, S.E., Erçağ, E. (2006). The cupric ion reducing antioxidant capacity (CUPRAC) and polyphenolic content of some herbal teas. International Journal of Food Sciences and Nutrition, 57(5-6), 292-304.

5. Awad, M.A., de Jager, A., van der Plas, L.W.H., van der Krol, A.R. (2001). Flavonoid and chlorogenic acid changes in skin of 'Elstar' and 'Jonagold' apples during development and ripening. Scientia Horticulturae, 90(1-2), 69-83.

6. Ben Ahmed, Z., Yousfi, M., Viaene, J., Dejaegher, B., Demeyer, K., Mangelings, D., Heyden, Y.V. (2017). Seasonal, gender and regional variations in total phenolic, flavonoid, and condensed tannins contents and in antioxidant properties from Pistacia atlantica ssp. leaves. Pharmaceutical Biology, 55(1), 1185-1194.
7. Bernatoniene, J., Masteikova, R., Majiene, D., Savickas, A., Kevelaitis, E., Bernatoniene, R., Dvorácková, K., Civinskiene, G., Lekas, R., Vitkevicius, K., Peciura, R. (2008). Free radical scavenging activities of Crataegus monogyna extracts. Medicina Lithuania, 44(9), 706-712.

8. Bleske, B.E., Koch, E., Aaronson, K., Boluyt, M.O. (2008). Hawthorn and heart disease. In R.R. Watson, V.R. Preedy (Eds.), Botanical Medicine in Clinical Practice. CAB International, Wallingford, UK, pp. 493-503.

9. Brand-Williams, W., Cuvelier, M.E., Berset, C. (1995). Use of a free radical method to evaluate antioxidant activity. $L W T-$ Food Science and Technology, 28(1), 25-30.

10. Bravo, L., Mateos, R. (2008). Analysis of flavonoids in functional foods and nutraceuticals. In W. Jeffrey Hurst (Ed.), Methods of Analysis for Functional Foods and Nutraceuticals, CRC Press, Boca Raton, Florida, USA, pp. 147-207.

11. Burda, S., Oleszek, W., Lee, C.Y. (1990). Phenolic compounds and their changes in apple during maturation and cold storage. Journal of Agricultural and Food Chemistry, 38(4), 945-948.

12. Cecarini, V., Gee, J., Fioretti, E., Amici, M., Angeletti, M., Eleuteri, A.M., Keller, J.N. (2007). Protein oxidation and cellular homeostasis: Emphasis on metabolism. Biochimica et Biophysica Acta (BBA) - Molecular Cell Research, 1773(2), 93-104.

13. Cezarotto, V.S., Giacomelli, S.R., Vendruscolo, M.H., Vestena, A.S., Cezarotto, C.S., da Cruz, R.C., Maurer, L.H., Ferreira, L.M., Emanuelli, T., Cruz, L. (2017). Influence of harvest season and cultivar on the variation of phenolic compounds composition and antioxidant properties in Vaccinium ashei leaves. Molecules, 22(10), art. no. 1603.

14. Ding, C.K., Chachin, K., Ueda, Y., Imahori, Y., Wang, C.Y. (2001). Metabolism of phenolic compounds during loquat fruit development. Journal of Agricultural and Food Chemistry, 49(6), 2883-2888.

15. Elmastas, M., Demir, A., Genç, N., Dölek, Ü., Günes, M. (2017). Changes in flavonoid and phenolic acid contents in some Rosa species during ripening. Food Chemistry, 235, 154-159.

16. Francini, A., Sebastiani, L., (2013). Phenolic compounds in apple (Malus $\times$ domestica Borkh.): Compounds characterization and stability during postharvest and after processing. Antioxidants, 2(3), 181-193.

17. Gao, P.Y., Li, L.Z., Peng, Y., Li, F.F., Niu, C., Huang, X.X., Ming, M., Song, S.J. (2010). Monoterpene and lignan glycosides in the leaves of Crataegus pinnatifida. Biochemical Systematics and Ecology, 38(5), 988-992.

18. Gucia, M., Jarzyńska, G., Rafal, E., Roszak, M., Kojta, A.K., Osiej, I., Falandysz, J. (2012). Multivariate analysis of mineral constituents of edible Parasol mushroom (Macrolepiota procera) and soils beneath fruiting bodies collected from Northern Poland. Environmental Science and Pollution Research, 19(2), 416-431.

19. He, F.Y., Li, D.W., Wang, D.M., Deng, M. (2016). Extraction and purification of quercitrin, hyperoside, rutin and afzelin from Zanthoxylum bungeanum Maxim. leaves using a aqueous two-phase system. Journal of Food Science, 81 (7), C1593-1602.

20. Heim, K.E., Tagliaferro, A.R., Bobilya, D.J. (2002). Flavonoid antioxidants, chemistry, metabolism and structure-activity relationship. Journal of Nutritional Biochemistry, 13(10), 572-584.

21. Hlel, T.B., Belhadj, F., Gül, F., Altun, M., Yağlığlu, A.Ş., Demirtaş, I., Marzouki, M.N. (2017). Variations in the bioactive compounds composition and biological activities of Loofah 
(Luffa cylindrica) fruits in relation to maturation stages. Chemistry and Biodiversity, 14(10), art. no. e1700178.

22. Huang, D., Ou, B., Prior, R.L. (2005). The chemistry behind antioxidant capacity assays. Journal of Agricultural and Food Chemistry, 53(6), 1841-1856.

23. Imeh, U., Khokhar, S. (2002). Distribution of conjugated and free phenols in fruits, antioxidant activity and cultivar variations. Journal of Agricultural and Food Chemistry, 50(22), 6301-6306.

24. Jaakola, L., Määttä, K., Pirttilä, A.M., Torronen, R., Karenlampi, S., Hohtola, A. (2002). Expression of genes involved in anthocyanin biosynthesis in relation to anthocyanin, proanthocyanidin, and flavonol levels during bilberry fruit development. Plant Physiology, 130(2), 729-739.

25. Kaiser, H.F. (1960). The application of electronic computers to factor analysis. Educational and Psychological Measurement, 20(1), 141-151.

26. Katalinic, V., Mozina, S. S., Skroza, D., Generalic, I., Abramovic, H., Milos, M., Ljubenkov, I., Piskernik, S., Pezo, I., Terpinc, P., Boban, M. (2010). Polyphenolic profile antioxidant properties and antimicrobial activity of grape skin extract of 14 Vitis vinifera varieties grown in Dalmatia (Croatia). Food Chemistry, 119, 715-723.

27. Kobayashi, S., Ishimaru, M., Ding, C.K., Yakushiji, H., Goto, N. (2001). Comparison of UDP-glucose, flavonoid 3-O-glucosyltransferase (UFGT) gene sequences between white grapes ( $\mathrm{Vi}$ tis vinifera) and their sports with red skin. Plant Science, 160(3), 543-550.

28. Krüger, E., Dietrich, H., Hey, M., Patz, C.D. (2011). Effects of cultivar, yield, berry weight, temperature and ripening stage on bioactive compounds of black currants. Journal of Applied Botany and Food Quality, 84, 40-46.

29. Kumar, D., Arya, V., Bhat, Z.A., Khan, N.A., Prasad, D.A. (2012). The genus Crataegus: chemical and pharmacological perspectives. Revista Brasileira de Farmacognosia, 22(5), 1187-1200.

30. Lee, C.Y., Kagan, V., Jaworski, A.W., Brown, S.K. (1990). Enzymatic browning in relation to phenolic compounds and polyphenoloxidase activity among various peach cultivars. Journal of Agricultural of Food Chemistry, 38(1), 99-101.

31. Liu, P., Kallio, H., Yang, B. (2011). Phenolic compounds in hawthorn (Crataegus grayana) fruits and leaves and changes during fruit ripening. Journal of Agricultural and Food Chemistry, 59(20), 11141-11149.

32. Manning, K. (1998). Isolation of a set ripening-related genes from strawberry, their identification and possible relationship to fruit quality traits. Planta, 205(4), 622-631.

33. Martz, F., Jaakola, L., Julkunen-Tiitto, R., Stark, S. (2010). Phenolic composition and antioxidant capacity of bilberry (Vaccinium myrtillus) leaves in Northern Europe following foliar development and along environmental gradients. Journal of Chemical Ecology, 36(9), 1017-1028.

34. Mishra, B., Priyadarsini, K.I., Kumar, M.S., Unnikrishnan, M.K., Mohan, H. (2003). Effect of O-glycosilation on the antioxidant activity and free radical reactions of a plant flavonoid, chrysoeriol. Bioorganic \& Medicinal Chemistry, 11 (13), 2677-2685.

35. Mitić, M.N., Souquet, J.M., Obradović, M.V., Mitić, S.S. (2012). Phytochemical profiles and antioxidant activity of Serbian table and wine grapes. Food Science and Biotechnology, 21(6), 1619-1626
36. Munhoz, V.M., Longhini, R., Souza, J.R.P., Zequi, J.A.C., Leite Mello, E.V.S., Lopes, G.C., Mello, J.C.P. (2014). Extraction of flavonoids from Tagetes patula: process optimization and screening for biological activity. Revista Brasileira de Farmacognosia, 24(5), 576-583.

37. Nikolov, N., Batyuk, V.S., Ivanov, V. (1973a). Crateside - A new flavonol glycoside from Crataegus monogyna and C. pentagyna. Chemistry of Natural Compounds, 9(2), 150-151.

38. Nikolov, N.T., Litvinenko, V.I., Kovalev, I.P. (1973b). Glogoside A new flavonoid from Crataegus pentagyna. Chemistry of Natural Compounds, 9(2), 144-146.

39. Nikolov, N.T. (1975). New flavone C-biosides from Crataegus monogyna and Cr. Pentagyna. Chemistry of Natural Compounds, $11(3), 434-435$.

40. Nikolov, N., Seligmann, O., Wagner, H., Horowitz, R.M., Gentili, B. (1982). New flavonoid-glycosides from Crataegus monogyna and Crataegus pentagyna. Planta Medica 44(1), 50-53.

41. Nurmi, K., Ossipov, V., Haukioja, E., Pihlaja, K. (1996). Variation of total phenolic content and individual low molecular weight phenolics in foliage of mountain birch trees (Betula pubescens spp. tortuosa). Journal of Chemical Ecology, 22 (11), 2023-2040.

42. Oyaizu, M. (1986). Studies on products of browning reaction: Antioxidative activity of products of browning reaction prepared from glucosamine. The Japanese Journal of Nutrition and Dietetics, 44(6), 307-315.

43. Prinz, S., Ringl, A., Huefner, A., Pemp, E., Kopp, B. (2007). 4"'-Acetylvitexin-2"-O-rhamnoside, isoorientin, orientin, and 8-methoxykaempferol-3-O-glucoside as markers for the differentiation of Crataegus monogyna and Crataegus pentagyna from Crataegus laevigata (Rosaceae). Chemistry \& Biodiversity, 4(12), 2920-2931.

44. Rayyan, S., Fossen, T., Solheim, H.N., Andersen, Ø.M. (2005). Isolation and identification of flavonoids, including flavone rotamers, from the herbal drug (hawthorn). Phytochemical Analysis, 16(5), 334-341.

45. Re, R., Pellegrini, N., Proteggente, A., Pannala, A., Yang, M., Rice-Evans, C. (1999). Antioxidant activity applying an improved ABTS radical cation decolorization assay. Free Radical Biology and Medicine, 26(9-10), 1231-1237.

46. Rice-Evans, C. A., Miller, N.J., Paganga, G. (1996). Structure-antioxidant activity relationships of flavonoids and phenolic acids. Free Radical Biology and Medicine, 20(7), 933-956.

47. Rimkiene, L., Kubiliene, A., Zevzikovas, A., Kazlauskiene, D., Jakstas, V. (2017). Variation in flavonoid composition and radicalscavenging activity in Ginkgo biloba L. due to the growth location and time of harvest. Journal of Food Quality, 2017, art. no. 6840397.

48. Romeyer, F.M., Macheix, J.J., Goiffon, J.P., Reminiac, C.C., Sapis, J.C. (1983). The browning capacity of grapes. 3. Changes and importance of hydroxycinnamic acid-tartaric acid esters during development and maturation of the fruit. Journal of Agricultural and Food Chemistry, 31 (2), 346-349.

49. Routray, W., Orsat, V. (2014). Variation of phenolic profile and antioxidant activity of North American highbush blueberry leaves with variation of time of harvest and cultivar. Industrial Crops and Products, 62, 147-155.

50. Singleton, V.L., Orthofer, R., Lamuela-Raventos, R.M. (1999). Analysis of total phenols and other oxidation substrates and antioxidants by means of Folin-Ciocalteu reagent. Oxidants and Antioxidants, PT A Book Series: Methods in Enzymology, 299, 152-178. 
51. Svedström, U., Vuorela, H., Kostiainen, R., Laakso, I., Hiltunen, R. (2006). Fractionation of polyphenols in hawthorn into polymeric procyanidins, phenolic acids and flavonoids prior to high-performance liquid chromatographic analysis. Journal of Chromatography A, 1112(1-2), 103-111.

52. Tadić, V.M., Dobrić, S., Marković, G.M., Đorđević, S.M., Arsić, I.A., Menković, N.R., Stević, T. (2008). Anti-inflamatory, gastroprotective, free-radical-scavenging, and antimicrobial activities of hawthorn berries ethanol extract. Journal of Agricultural and Food Chemistry, 56(17), 7700-7709.

53. Tiwari, U., Cummins, E. (2013). Factors influencing levels of phytochemicals in selected fruit and vegetables during preand post-harvest food processing operations. Food Research International, 50(2), SI, 497-506.

54. Vagiri, M., Conner, S., Stewart, D., Anderson, S.C., Verrall, S., Johansson, E., Rumpunen, K. (2015). Phenolic compounds in blackcurrant (Ribes nigrum L.) leaves relative to leaf position and harvest date. Food Chemistry, 172, 135-142.

55. Wang, S.Y., Lin, H.S. (2000). Antioxidant activity in fruits and leaves of blackberry, raspberry and strawberry varies with cultivar and development stage. Journal of Agricultural and Food Chemistry, 48(2), 140-146.

56. Yang, B., Liu, P. (2012). Composition and health effects of phenolic compounds in hawthorn (Crataegus spp.) of different origins. Journal of the Science of Food and Agriculture, 92(8), 1578-1590.

57. Zhao, H.C., Tian, B.F. (1996). China Fruit-Plant MonographHawthorn Flora. Forestry Publishing House, Bejing, China, p. 366 .

Submitted: 18 October 2018. Revised: 18 March, 10 June, and 17 July 2019. Accepted: 29 August 2019. Published on-line: 7 November 2019. 